\title{
Insecticide resistance through mutations in cholinesterases or carboxylesterases: data mining in the ESTHER database
}

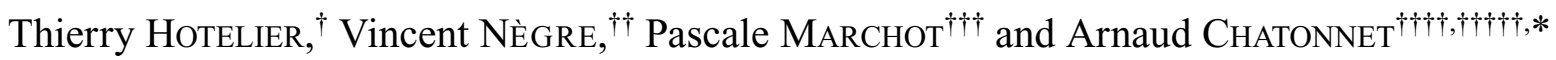 \\ †Unité Informatique de Centre, INRA-SupAgroM, F-34060 Montpellier, France \\ ${ }^{\dagger}$ Laboratoire d'Ecophysiologie des Plantes sous Stress Environnementaux (LEPSE) \\ INRA-SupAgro, F-34060, Montpellier, France \\ ${ }^{\dagger \dagger}$ Centre de Recherche en Neurobiologie-Neurophysiologie de Marseille (CRN2M), CNRS/Universités Aix-Marseille UMR-6231, \\ Institut Fédératif de Recherche Jean Roche, \\ Faculté de Médecine-Secteur Nord, F-13344 Marseille, France \\ ${ }^{\dagger \dagger \dagger}$ Différenciation Cellulaire et Croissance, INRA, UMR 866, F-34060 Montpellier, France \\ †iti† Université de Montpellier Sud de France, F-34967 Montpellier, France
}

(Received April 30, 2010; Accepted June 19, 2010)

\begin{abstract}
Resistance of arthropods to organophosphates and carbamates used as insecticides is mainly due to mutations in genes encoding carboxylesterase or acetylcholinesterase members of the alpha/beta-hydrolase fold superfamily of proteins. Mutations that have been described at the molecular level concern 24 species, 31 genes and 32 identical positions in the aligned aminoacid sequences. Seven of these positions are found in more than four species and can be considered as hot spots for mutations. Mutations in one single gene also result in cross resistance to pyrethroids. These figures along with all pieces of information related to these mutations can be recovered from the ESTHER database, dedicated to the alpha/beta-hydrolase fold superfamily (http://bioweb.ensam.inra.fr/ esther), through built-in or custom made queries. A sequence alignment of enzymes involved in resistance with highlighted mutated amino acid residues is provided. Selecting one amino acid residue leads to all information about mutations analyzed at this position. Links to the related literature are also available. (C) Pesticide Science Society of Japan
\end{abstract}

Keywords: acetylcholinesterase, alpha/beta-hydrolase fold, carbamate, carboxylesterase, cholinesterase, ESTHER database, insecticide resistance, mutation, organophosphate.

\section{Introduction}

The analysis of origin and molecular mechanisms of resistance to pesticides by arthropods is a very active field of research. Most insecticides act on the nervous system at synaptic sites. Organophosphates (OPs) and carbamates, which inhibit acetylcholinesterase (AChE) and prolong the excitatory action of acetylcholine (ACh), are still the dominant insecticides in terms of number and quantities of compounds used, and market value. ${ }^{1)}$ In the case of resistance to OPs and carbamates, the activity of unspecific detoxification enzymes such as glutathione-S-transferase or mixed-function

\footnotetext{
* To whom correspondence should be addressed.

E-mail: chatonne@supagro.inra.fr

Published online August 7, 2010

(C) Pesticide Science Society of Japan
}

oxidases is often increased in resistant pests, although most of the proteins involved in strain adaptation belong to the carboxylesterase or cholinesterase families. ${ }^{2-4)}$ Genome modifications that give rise to resistance are very diverse and include: point mutations in the genes encoding the insecticide targets, amplification of esterase genes resulting in over-expressed proteins that sequester the insecticides, mutations that transform a carboxylesterase into an OP hydrolase, and amplification of a resistant AChE gene. However all these modifications do not generate a same level of resistance and fitness cost. Comparative analysis of the numerous experiments and species concerned by this mode of selective pressure are necessary. Only a database compilation strategy can retrieve this overwhelming flow of information in a structured way. The ESTHER database, which was created 15 years ago, gathers and annotates all the published information related to members of the alpha/beta-hydrolase fold along with bio- 
Table 1. Genes, mutations, species, Torpedo_number and references displayed in this table were gathered as a table from a query available at : http://bioweb.ensam.inra.fr/ESTHER/general?what=aqlinsectresist.

\begin{tabular}{|c|c|c|c|c|c|}
\hline Gene/Taxon & Species & Enzyme & Torpedo_number & Mutations & Ref. \\
\hline \multicolumn{6}{|l|}{ acel } \\
\hline \multicolumn{6}{|l|}{ Diptera } \\
\hline & Anopheles gambiae & anoga-acche 1 & 119 & G119S & $13-16$ \\
\hline & Culex pipiens & culpi-acche1 & 119,290 & G119S, F416V & $17-21$ \\
\hline & Culex tritaeniorhynchus & cultr-acche1 & 331 & F455W & 17,23 \\
\hline \multicolumn{6}{|l|}{ Lepidoptera } \\
\hline & Cydia pomonella & cydpo-acche 1 & 290 & F399V & 24 \\
\hline & Chilo suppressalis & 9neop-acche1 & 201 & A314S & 25 \\
\hline & Plutella xylostella & pluxy-acche1 & $131,201,227,441$ & D131G, A201S, & \\
\hline & & & & G227A, A441G & 26,27 \\
\hline \multicolumn{6}{|l|}{ Hemiptera } \\
\hline & Aphis gossypii & aphgo-acche1 & 201,331 & A302S/S431F, S431F & $28-32$ \\
\hline & Bemisia tabaci & bemta-acche1 & 331 & F392W & 33 \\
\hline & Myzus persicae & myzpe-acchem & 331 & S431F & $34-37$ \\
\hline & Rhopalosiphum padi & rhopd-acche 1 & 228 & S329P & 38 \\
\hline & Sitobion avenae & sitav-acche1 & 336 & L436S & 39 \\
\hline \multicolumn{6}{|c|}{ Arachnida Acari } \\
\hline & Boophilus microplus & boomi-acche1 & $131,140,275,336$ & D188G/E196G/V331A & 40 \\
\hline & & & & /F390S & \\
\hline & Tetranychus kanzawai & tetka-acche & 331 & F439W & 41 \\
\hline & Tetranychus urticae & tetur-acche & $201,280,328,331$ & $\begin{array}{l}\text { A201S, T280A, G328A, } \\
\text { F439C/W/Y }\end{array}$ & $42-44$ \\
\hline \multicolumn{6}{|l|}{ ace 2} \\
\hline \multicolumn{6}{|l|}{ Diptera } \\
\hline & Aedes aegypti & aedae-acche & $78,227,288$ & F105S, G285A, F350Y & 45 \\
\hline & Bactrocera dorsalis & bacdo-acche & 129,396 & I214V/G488S/Q643R & 46 \\
\hline & Bactrocera oleae & bacol-acche & $129,396,551,552$ & $\mathrm{I} 214 \mathrm{~V}, \mathrm{G} 488 \mathrm{~S}$ & \\
\hline & & & 553,554 & Q642-644del & $47-51$ \\
\hline & Ceratitis capitata & cerca-acche & 328 & G328A & 52 \\
\hline & Drosophila melanogaster & drome-acche & $70,72,74,78,84,121$ & E107+A, E107A, E107o, & $53-59$ \\
\hline & & & $129,130,199,227,276$ & Y109A, Y111A, F115S, & \\
\hline & & & $279,284,288,290,328$ & W121A, W121Y, M191A, & \\
\hline & & & $330,331,334,335$ & $\mathrm{I} 199 \mathrm{~A} / \mathrm{E} / \mathrm{G} / \mathrm{K} / \mathrm{R} / \mathrm{T} / \mathrm{W}$ & \\
\hline & & & & Y200A, E275A, E275Q, & \\
\hline & & & & G303A, V356A, W359+A, & \\
\hline & & & & W359A, W359o, Y362A, & \\
\hline & & & & L366A, L366F, F368A, & \\
\hline & & & & $\mathrm{F} 368 \mathrm{C} / \mathrm{H} / \mathrm{I} / \mathrm{L} / \mathrm{S} / \mathrm{V} / \mathrm{W} / \mathrm{Y}$ & \\
\hline & & & & G406A, Y408A/F, F409A, & \\
\hline & & & & Y412+A, Y412A, Y412o, & \\
\hline & & & & D413A, & \\
\hline & Haematobia irritans & haeir-acche & 227 & G262A & 60 \\
\hline & Lucilia cuprina & luccu-acche & $78,78,129,227,290$ & $\begin{array}{l}\text { F115S, I199T/V, G303A, } \\
\text { F368Y }\end{array}$ & 59 \\
\hline
\end{tabular}


Table 1. Continued.

\begin{tabular}{|c|c|c|c|c|c|}
\hline Gene/Taxon & Species & Enzyme & Torpedo_number & Mutations & Ref. \\
\hline & Musca domestica & musdo-acche & $\begin{array}{l}83,150,195,227,290 \\
304,32\end{array}$ & $\begin{array}{l}\text { I82M, V180L, T230M, } \\
\text { G262A/V, F327Y, D341L, } \\
\text { G365A, A586T }\end{array}$ & $61-68$ \\
\hline \multicolumn{6}{|l|}{ Coleoptera } \\
\hline & Leptinotarsa decemlineata & lepde-acche & $-6,238,337$ & R30K, S291G, I392T & $69-74$ \\
\hline \multicolumn{6}{|l|}{ Hemiptera } \\
\hline & Aphis gossypii & aphgo-acche2 & 78 & F139L & 28,30 \\
\hline & Rhopalosiphum padi & rhopd-acche2 & 290,356 & F368L, V435 & 38 \\
\hline & Sitobion avenae & sitav-acche 2 & 435 & W516R & 39 \\
\hline \multicolumn{6}{|l|}{ ace3 } \\
\hline \multicolumn{6}{|l|}{ Arachnida Acari } \\
\hline & Boophilus microplus & boomi-acche 3 & & R86Q & 75,76 \\
\hline \multicolumn{6}{|l|}{ Carboxylesterase } \\
\hline \multicolumn{6}{|l|}{ Diptera } \\
\hline & Cochliomyia hominivorax & cocho-E3aest7 & 119,233 & G137D, W251S & $77-80$ \\
\hline & Drosophila melanogaster & drome-EST23aes07 & 119,233 & G137D, W251L & 81 \\
\hline & Lucilia cuprina & luccu-E3aest7 & $\begin{array}{l}119,130,233,199,232, \\
233,290,330\end{array}$ & $\begin{array}{l}\mathrm{G} 137 \mathrm{D} / \mathrm{E} / \mathrm{H} / \mathrm{R}, \mathrm{Y} 148 \mathrm{~F}, \\
\mathrm{E} 217 \mathrm{M}, \mathrm{W} 251 \mathrm{~A} / \mathrm{G} / \mathrm{L} / \mathrm{S} / \mathrm{T}, \\
\text { F309L, F354/W }\end{array}$ & $81-87$ \\
\hline & Musca domestica & musdo-EST23aes07 & 119,233 & G137D, W251S, W251C & $88-92$ \\
\hline \multicolumn{6}{|l|}{ Hymenoptera } \\
\hline & Anisopteromalus calandrae & anica-cxest & 233 & W220G & 93 \\
\hline \multicolumn{6}{|l|}{ Hemiptera } \\
\hline & Aphis gossypii & aphgo-cxest & 17,376 & $\mathrm{~K} 14 \mathrm{Q} / \mathrm{N} 354 \mathrm{D}$ & 94 \\
\hline \multicolumn{6}{|l|}{ Arachnida } \\
\hline & Boophilus microplus & boomi-este 13 & 346 & D374N & 95 \\
\hline
\end{tabular}

chemical, pharmacological and structural data. ${ }^{5-10)}$ The carboxylesterase/cholinesterase family (PF00135 COesterase in PFAM database ${ }^{11)}$ ) evolved from a core alpha/beta-hydrolase. ${ }^{12)}$ Members of this family are numerous in the fungi/metazoa lineage and occupy a prominent place in the ESTHER database. More recently, various tools were developed and included in the database for analysis of natural or directed mutations in members of the alpha/beta-hydrolases, and more specifically the carboxylesterases and cholinesterases. $^{8-10)}$

\section{Alignments of Mutated Sequences}

The Mutalign tool displays an alignment of cholinesterases where mutated amino acid residues (either naturally or experimentally) are highlighted and can be selected on a web page. This leads to description of the mutation and its structural/ functional effect/impact and bibliographic references can be retrieved. Although equivalent positions in cholinesterase or carboxylesterase sequences from two species may be de- scribed with different numbers depending on the size of the signal peptide or different insertions/deletions, an international consensus has emerged for using the numbering of Torpedo californica $\mathrm{AChE}$ as a universal reference. In the ESTHER database this numbering system is referred to as the "Torpedo_number". Selecting a Torpedo_number directs the user towards all the information available on mutations at this particular position in any cholinesterase or carboxylesterase. The original Mutalign presented only the aligned sequences of Torpedo, human, mouse and drosophila AChEs and of human butyrylcholinesterase (i.e., those proteins for which the greatest number of mutations had been studied). We devised a new alignment specifically dedicated to analysis of insecticide resistance. (http://bioweb.ensam.inra.fr/ESTHER/general? what $=$ mutalignresist) This alignment includes 34 sequences from 24 species. The Torpedo californica AChE sequence is also included to provide access to the Torpedo_number reference. On top of each column of aligned amino-acid residues, a link represented by a "?" (question mark) leads to the corre- 
Table 2. Table of genes amplified or duplicated in OP or carbamate resistant insect strains.

\begin{tabular}{lllll}
\hline ESTHER Gene_locus & \multicolumn{1}{c}{ Gene } & \multicolumn{1}{c}{ Species } & \multicolumn{1}{c}{ Organism } & References \\
\hline culpi-est2, culpi-est3 & Est-2 (EstB), Est-3 (EstA) & Culex pipiens complex & (Mosquitoe) Diptera & $96-99$ \\
myzpe-este4, myzpe-estf4 & E4 FE4 & Myzus persicae & (Peach-potatoe aphid) Hemiptera & 100,101 \\
bemta-coe1 & coe1 & Bemisia tabaci & (Sweetpotato whitefly) Hemiptera & 33 \\
nillu-est1 & Nl-EST1 & Nilaparvata lugens & (Brown planthopper) Hemiptera & 102,103 \\
schga-est1 & SG1 & Schizaphis graminum & (Greenbug) (Aphid) Hemiptera & 104 \\
F290V_culpi-acche1 & ace1 & Culex pipiens & (Mosquitoe) Diptera & 20 \\
G119S_anoga-acche1 & ace1 & Anopheles gambiae & (Mosquitoe) Diptera & 105,106 \\
G228S/A391T/F439W_- & ace1 & Tetranychus urticae & (Archnid) Acari & 107 \\
\multicolumn{1}{c}{ tetur-acche1 } & & & &
\end{tabular}

sponding Torpedo_number page with all the mutations studied in this position in any species. The "?" is replaced by a "!" (exclamation mark) when no mutation related to insecticide resistance was described at this particular position while experimental mutations were analyzed in enzymes from other species.

\section{Complex Queries}

The original ACeDB software used to run the database includes both simple queries based on keywords (Simple search, Text search, Class Browser) and more complex queries interconnecting several database objects (Ace Query, AQL Query). Recently a new page was built with different queries related to insecticide resistance.(http://bioweb.ensam. inra.fr/ESTHER/general?what=aqlinsectresist). For example one can retrieve a list of publications reporting analysis of natural mutations in carboxylesterases/cholinesterases related to insecticide resistance, with access to all genes and species

select $p, g, s$ from $m$ in class Mutation, $g$ in $m->$ Gene_locus, $\mathbf{n}$ in $\mathbf{m}->$ Modification where $\mathbf{n}$ like "OP-*" or $n$ like "ins"" or $n$ like "Pyr", $f$ in $g->$ Family where $f$ like "AChE" or f like "BuChE" or f like "Carboxylesterase" or $f$ like "Cholin*", $s$ in $g->$ Species, $t$ in s- $>$ Tax_id where $t$ like "33208", $u$ in m->Mode_of_mutation where u like "Nat*", $p$ in $\mathbf{m}->$ Paper order by :p

analyzed in these publications.

\section{The Query Is:}

The query can be cut and past in the space available in the query page. The tables can be recovered in plain text format and easily introduced in any word processor or tabulator in order to build customized output reports. Table 1 shows a compilation of all mutations related to insecticide resistance in arthropods. The Torpedo_numbers and related references are included.

Many resistant strains of insects show increased carboxylesterase activity. In some cases the increased enzyme production results not only from increased transcription of the carboxylesterase genes but also from increased number of copies of those genes in the genome of the resistant insects. Table 2 lists genes that have been amplified or duplicated. Two genes, Est-2 and Est-3, adjacent in the genome of Culex mosquitoes, constitute the Ester super locus. More than 16 alleles are known at this locus and at least 12 of them are associated with insecticide resistance. Two types of amplification are known, one (A) that co-amplifies Est-2 and Est-3, and one (B) that amplifies only Est-2. ${ }^{97)}$ Recently a new allele with Est-3 and Est-2 amplification at a ratio close to $2: 1$ was described. ${ }^{98)}$ Amplified carboxylesterase genes were described also in various Hemiptera species. In Mysus persicae two adjacent genes are amplified in tandem in some resistant strains.

The size of the amplicon and the different mutations accumulated in the amplified sequence distinguish alleles with different geographical spreading. Number of amplicons, transcription levels of amplified genes and tissue distribution result in various levels of resistance. ${ }^{97}$ ) Duplication of the AChE target gene was described only for resistant alleles in mosquitoes. Probably only mutated AChE with reduced cholinesterase activity can be amplified without generating a high fitness cost.

\section{Perspectives}

New database classes associated to loci should be introduced in order to include information on haplotypes, intergenic variations, and single nucleotide polymorphism. Since data related to mutations have to be introduced in the database manually from publications, all inputs spontaneously provided by users of the database will be most welcome, and they will be properly acknowledged.

\section{References}

1) J. E. Casida: Chem. Res. Toxicol. 22, 609-619 (2009).

2) L. Pezzementi and A. Chatonnet: Chem. Biol. Interact. doi:10.1016/j.cbi.2010.03.043 in press (2010).

3) J. G. Oakeshott, A. L. Devonshire, C. Claudianos, T. D. 
Sutherland, I. Horne, P. M. Campbell, D. L. Ollis and R. J. Russell: Chem. Biol. Interact. 157-158, 269-275 (2005).

4) C. E. Wheelock, G. Shan and J. Ottea: J.Pestic.Sci. 30, 75-83 (2005).

5) X. Cousin, T. Hotelier, P. Lievin, J. P. Toutant and A. Chatonnet: Nucleic Acids Res. 24, 132-136 (1996).

6) X. Cousin, T. Hotelier, K. Giles, P. Lievin, J. P. Toutant and A. Chatonnet: Nucleic Acids Res. 25, 143-146 (1997).

7) X. Cousin, T. Hotelier, K. Giles, J. P. Toutant and A. Chatonnet: Nucleic Acids Res. 26, 226-228 (1998)

8) A. Chatonnet, T. Hotelier and X. Cousin: Chem. Biol. Interact. 119-120, 567-576 (1999).

9) A. Chatonnet, X. Cousin and A. Robinson: Brief Bioinform. 2, 30-37 (2001).

10) T. Hotelier, L. Renault, X. Cousin, V. Negre, P. Marchot and A. Chatonnet: Nucleic Acids Res. 32, D145-147 (2004).

11) R. D. Finn, J. Mistry, J. Tate, P. Coggill, A. Heger, J. E. Pollington, O. L. Gavin, P. Gunasekaran, G. Ceric, K. Forslund, L. Holm, E.L. Sonnhammer, S.R. Eddy and A. Bateman: Nucleic Acids Res. 38, D211-D222 (2010)

12) L. Pezzementi, and A. Chatonnet: Chem. Biol. Interact. doi:10.1016/j.cbi.2010.03.043 (2010)

13) M. Weill, G. Lutfalla, K. Mogensen, F. Chandre, A. Berthomieu, C. Berticat, N. Pasteur, A. Philips, P. Fort and M. Raymond: Nature 423, 136-137 (2003).

14) M. Weill, C. Malcolm, F. Chandre, K. Mogensen, A. Berthomieu, M. Marquine and M. Raymond: Insect. Mol. Biol. 13, 1-7 (2004).

15) C. Bass, Nikou, J. Vontas, M.S. Williamson and L. M. Field: Pestic. Biochem. Physiol. 96, 80-85 (2010).

16) L. Djogbenou, M. Weill, J. M. Hougard, M. Raymond, M. Akogbeto and F. Chandre: J. Med. Entomol. 44, 805-810 (2007).

17) H. Alout, A. Berthomieu, F. Cui, Y. Tan, C. Berticat, C. Qiao and M. Weill: J. Med. Entomol. 44, 463-469 (2007).

18) H. Alout, A. Berthomieu, A. Hadjivassilis and M. Weill: Insect Biochem. Mol. Biol. 37, 41-47 (2007).

19) H. Alout and M. Weill: Chem. Biol. Interact. 175, 138-141 (2008).

20) H. Alout, P. Labbé, A. Berthomieu, N. Pasteur and M. Weill: Insect. Biochem. Mol. Biol. 39, 884-891 (2009).

21) F. Cui, M. Raymond, A. Berthomieu, H. Alout, M. Weill and C. L. Qiao: J. Med. Entomol. 43, 878-883 (2006).

22) P. Labbe, A. Berthomieu, C. Berticat, H. Alout, M Raymond, T. Lenormand and M. Weill: Mol. Biol. Evol. 24, 1056-1067 (2007).

23) T. Nabeshima, A. Mori, T. Kozaki, Y. Iwata, O. Hidoh, S. Harada, S. Kasai, D. W. Severson, Y. Kono and T. Tomita: Biochem. Biophys. Res. Commun. 313, 794-801 (2004).

24) S. Cassanelli, M. Reyes, M. Rault, G. Carlo Manicardi and B Sauphanor: Insect. Biochem. Mol. Biol. 36, 642-653 (2006).

25) X. Jiang, M. Qu, I. Denholm, J. Fang, W. Jiang and Z. Han: Biochem. Biophys. Res. Commun. 378, 269-272 (2009).

26) D. W. Lee, J. Y. Choi, W. T. Kim, Y. H. Je, J. T. Song, B. K Chung, K. S. Boo and Y. H. Koh: Biochem. Biophys. Res. Commun. 353, 591-597 (2007).

27) J. H. Baek, J. I. Kim, D. W. Lee, B. K. Chung, T. Miyata and S. H. Lee: Pestic. Biochem. Physiol. 81, 164-175 (2005).

28) F. Li and Z. Han: Insect Biochem. Mol. Biol. 34, 397-405
(2004).

29) M. C. Andrews, A. Callaghan, L. M. Field, M. S. Williamson and G. D. Moores: Insect. Mol. Biol. 13, 555-561 (2004).

30) S. Toda, S. Komazaki, T. Tomita and Y. Kono: Insect. Mol. Biol. 13, 549-553 (2004).

31) J. Carletto, T. Martin, F. Vanlerberghe-Masuti and T. Brévault: Pest. Manag. Sci. 66, 301-307 (2010).

32) J. Benting and R. Nauen: Pest. Manag. Sci. 60, 1051-1055 (2004).

33) M. Alon, F. Alon, R. Nauen and S. Morin: Insect Biochem. Mol. Biol. 38, 940-949 (2008).

34) T. Nabeshima, T. Kozaki, T. Tomita and Y. Kono: Biochem. Biophys. Res. Commun. 307, 15-22 (2003).

35) S. Cassanelli, B. Cerchiari, S. Giannini, D. Bizzaro, E. Mazzoni and G.C. Manicardi: Pest. Manag. Sci. 61, 91-96 (2005).

36) A. Criniti, E. Mazzoni, S. Cassanelli, P. Cravedi, A. Tondelli, D. Bizzaro and G.C. Manicardi: Pestic. Biochem. Physiol. 90, 168-174 (2008).

37) D. H. Kwon, B. R. Choi, S. W. Lee, J. M. Clark and S. H. Lee: Pestic. Biochem. Physiol. 93, 120-126 (2009).

38) M. H. Chen, Z. J. Han, X. F. Qiao and M. J. Qu: Genome 50, $172-179$ (2007).

39) M. Chen, Z. Han, X. Qiao and M. Qu: Pestic. Biochem. Physiol. 87, 189-195 (2007).

40) K. B. Temeyer, J. H. Pruett and P. U. Olafson: Vet. Parasitol. Entomol. doi:10.1016/j.vetpar.2010.04.016 (2010).

41) Y. Aiki, T. Kozaki, H. Mizuno and Y. Kono: Pestic. Biochem. Physiol. 82, 154-161 (2005)

42) J. Khajehali, T. Van Leeuwen, M. Grispou, E. Morou, H. Alout, M. Weill, L. Tirry, J. Vontas and A. Tsagkarakou: Pest. Manag. Sci. 66, 220-228 (2010).

43) Y. Anazawa, T. Tomita, Y. Aiki, T. Kozaki and Y. Kono: Insect. Biochem. Mol. Biol. 33, 509-514 (2003).

44) D. H. Kwon, J. S. Im, J. J. Ahn, J.-H. Lee, J. M. Clark, S. H. Lee: Pestic. Biochem. Physiol. 96, 36-42 (2010).

45) A. Vaughan, T. Rocheleau, R. Ffrench-Constant: Exp. Parasitol. 87, 237-244 (1997).

46) J. C. Hsu, D. S. Haymer, W. J. Wu and H. T. Feng: Insect Biochem. Mol. Biol. 36, 396-402 (2006).

47) J. C. Hsu, W. J. Wu, D. S. Haymer and H. T. Feng: Insect Biochem. Mol. Biol. 38, 146-154 (2008).

48) N. J. Hawkes, W. Janes, J. Hemingway and J. Vontas: Pestic. Biochem. Physiol. 81, 154-163 (2005).

49) F. Nardi, A. Carapelli, J. G. Vontas, R. Dallai, G. K. Roderick and F. Frati: Insect Biochem. Mol. Biol. 36, 593-602 (2006).

50) E. G. Kakani, I. M. Ioannides, J. T. Margaritopoulos, N. A. Seraphides, P. J. Skouras, J. A. Tsitsipis and K. D. Mathiopoulos: Insect. Biochem. Mol. Biol. 38, 781-787 (2008).

51) J. G. Vontas, M. J. Hejazi, N. J. Hawkes, N. Cosmidis, M. Loukas, R. W. Janes and J. Hemingway: Insect. Mol. Biol. 11, 329-336 (2002).

52) C. Magana, P. Hernandez-Crespo, A. Brun-Barale, F. Couso-Ferrer, J. M. Bride, P. Castanera, R. Feyereisen and F. Ortego: Insect Biochem. Mol. Biol. 38, 756-762 (2008).

$53)$ A. Mutero, M. Pralavorio, J. M. Bride, D. Fournier: Proc. Natl. Acad. Sci. U.S.A. 91, 5922-5926 (1994)

54) P. Menozzi, M. A. Shi, A. Lougarre, Z. H. Tang and D. Fournier: BMC. Evol. Biol. 4, 4 (2004). 
55) Y. Boublik, P. Saint-Aguet, A. Lougarre, M. Arnaud, F. Villatte, S. Estrada-Mondaca and D. Fournier: Protein. Eng. 15, 43-50 (2002).

56) F. Fan, Z. You, Z. Li, J. Cheng, Y. Tang and Z. Tang: J. Mol. Model. 15, 1229-1236 (2009).

57) V. Marcel, S. Estrada-Mondaca, F. Magne, J. Stojan, A. Klaebe and D. Fournier: J. Biol. Chem. 275, 11603-11609 (2000).

58) J. Stojan, V. Marcel, S. Estrada-Mondaca, A. Klaebe, P. Masson and D. Fournier: FEBS. Lett. 440, 85-88 (1998).

59) K. B. Temeyer, A. Y. Li, K. H. Lohmeyer, A. C. Chen, P. U. Olafson, D. W. Sanson and L. D. Foil: Vet. Parasitol. 154, 300-310 (2008).

60) Z. Chen, R. Newcomb, E. Forbes, J. McKenzie and P. Batterham: Insect Biochem. Mol. Biol. 31, 805-816 (2001).

61) C. S. Kim, W. T. Kim, K. S. Boo and S. I. Kim: Mol. Cells, 15, 208-215 (2003).

62) T. Kozaki, T. Shono, T. Tomita and Y. Kono: Insect Biochem. Mol. Biol. 31, 991-997 (2001).

63) T. Kozaki S. G. Brady and J. G. Scott: Pestic. Biochem. Physiol 95, 6-11 (2009).

64) M. Kristensen, J. Huang, C. L. Qiao and J. B. Jespersen: Pest Manag. Sci. 62, 738-745 (2006).

65) S. B. Walsh, T. A. Dolden, G. D. Moores, M. Kristensen, T. Lewis, A. L. Devonshire and M. S. Williamson: Biochem. J. 359, 175-181 (2001).

66) T. Liming, S. Mingan, Y. Jiangzhong, Z. Peijun, Z. Chuanxi and T. Zhenhua: Pestic. Biochem. Physiol. 86, 1-6 (2006).

67) Y. Huang, C. Qiao, M. S. Williamson and A. L. Devonshire: Chin. J. Biotechnol. 13, 177-183 (1997).

68) A. L. Devonshire, F. J. Byrne, G. D. Moores and M. S. Williamson: "Structure and Function of Cholinesterases and Related Proteins" ed by B. P. Doctor, P. Taylor, D. M. Quinn, R. L. Rotundo and M. K. Gentry, Plenum, New York, pp 491-496, (1998).

69) K. Y. Zhu, S. H. Lee and J. M. Clark: Pestic. Biochem. Physiol. 55, 100-108 (1996).

70) K. Y. Zhu and J. M. Clark: Pestic. Biochem. Physiol. 57, 28-35 (1997).

71) H. J. Kim, J. B. Dunnb, K. S. Yoon and J. M. Clark: Pestic. Biochem. Physiol. 84, 165-179 (2006).

72) H. J. Kim, K. S. Yoon and J. M. Clark: Pestic. Biochem. Physiol. 88, 181-190 (2007).

73) A. Zhang, J. B. Dunnb and J. M. Clark: Pestic. Biochem Physiol. 65, 25-35 (1999).

74) J. M. Clark, S. H Lee, H. J. Kim, K. S. Yoon and A. Zhang: Pest. Manag. Sci. 57, 968 (2001).

75) K. B. Temeyer, J. H. Pruett, P. U. Olafson and A. C. Chen: $J$. Med. Entomol. 44, 1013-1018 (2007).

76) K. B. Temeyer, P. U. Olafson and R. J. Miller: J. Med. Entomol. 46, 1355-1360 (2009).

77) R. A. Carvalho, T. T. Torres, M. G. Paniago and A. M. Azeredo-Espin: Med. Vet. Entomol. 23, Suppl 1, 86-91 (2009).

78) R. A. de Carvalho, T. T. Torres and A. M. de Azeredo-Espin: Vet. Parasitol. 140, 344-351 (2006).

79) N. M. da Silva and A. M. de Azeredo-Espin: Genet. Mol. Res. 8, 1067-1078 (2009).

80) R. A. de Carvalho, C. E. Gomez Limia, C. Bass, A. M. Lima de Azeredo-Espin: Vet. Parasitol. 170, 297-301 (2010)

81) R. Heidari, A. L. Devonshire, B. E. Campbell, S. J. Dorrian, J.
G. Oakeshott and R. J. Russell: Insect Biochem. Mol. Biol. 35, 597-609 (2005).

82) A. L. Devonshire, R. Heidari, H. Z. Huang, B. D. Hammock, R. J. Russell and J. G. Oakeshott: Insect Biochem. Mol. Biol. 37, 891-902 (2007).

83) R. Heidari, A. L. Devonshire, B. E. Campbell, K. L. Bell, S. J. Dorrian, J. G. Oakeshott and R. J. Russell: Insect Biochem. Mol. Biol. 34, 353-363 (2004).

84) R. D. Newcomb, D. M. Gleeson, C. G. Yong, R. J. Russell and J. G. Oakeshott: J. Mol. Evol. 60, 207-220 (2005).

85) R. D. Newcomb, P. M. Campbell, D. L. Ollis, E. Cheah, R. J. Russell and J. G. Oakeshott: Proc. Natl. Acad. Sci. U.S.A. 94, 7464-7468 (1997).

86) P. M. Campbell, R. D. Newcomb, R. J. Russell and J. G. Oakeshott: Insect Biochem. Mol. Biol. 28, 139-150 (1998).

87) C. J. Hartley, R. D. Newcomb, R. J. Russell, C. G. Yong, J. R. Stevens, D. K. Yeates, J. La Salle and J. G. Oakeshott: Proc. Natl. Acad. Sci. U. S. A. 103, 8757-8762 (2006).

88) C. Claudianos, R. J. Russell and J. G. Oakeshott: Insect Biochem. Mol. Biol. 29, 675-686 (1999).

89) V. Taskin, M. Kence and B. Gocmen: Genetika 40, 478-481 (2004).

90) V. Taskin and M. Kence: Genetika 40, 1475-1482 (2004).

91) F. Gacar and V. Taskin: Pestic. Biochem. Physiol. 94, 86-92 (2009).

92) L. Zhang, J. Shi, X. Shi, P. Liang, J. Gao and X. Gao: Comp. Biochem. Physiol. B. Biochem. Mol. Biol. 156, 6-11 (2010).

93) Y. C. Zhu, A. K. Dowdy and J. E. Baker: Insect Biochem. Mol. Biol. 29, 417-425 (1999).

94) Y. Pan, H. Guo and X. Gao: Comp. Biochem. Physiol. B. Biochem. Mol. Biol. 152, 266-270 (2009).

95) R. Hernandez, H. He, A. C. Chen, S. D. Waghela, G. Wayne Ivie, J. E. George and G. Gale Wagner: Insect. Biochem. Mol. Biol. 30, 969-977 (2000).

96) C. Mouches, N. Pasteur, J. B. Berge, O. Hyrien, M. Raymond, B. R. De Saint Vincent, M. de Silvestri and G. P. Georghiou: Science 233, 778-780 (1986).

97) S. Rooker, T. Guillemaud, J. B. Berge, N. Pasteur and M. Raymond: Heredity 77, 555-561 (1996).

98) M. Raymond, C. Berticat, M. Weill, N. Pasteur and C. Chevillon: Genetica. 112-113, 287-296 (2001).

99) F. Cui, M. Weill, A. Berthomieu, M. Raymond and C. L. Qiao: Insect Biochem. Mol. Biol. 37, 1137-1139 (2007).

100) L.M. Field and A.L. Devonshire: Biochem. J. 322, 867-871 (1997)

101) L. M. Field, N. Javed, M. F. Stribley and A. L. Devonshire: Insect Mol. Biol. 3, 143-148 (1994).

102) J. G. Vontas, G. J. Small and J. Hemingway: Insect Mol. Biol. 9, 655-660 (2000).

103) G. J. Small and J. Hemingway: Insect Mol. Biol. 9, 647-653 (2000).

104) M. Ono, J. J. Swanson, L. M. Field, A. L. Devonshire and B. D. Siegfried: Insect Biochem. Mol. Biol. 12, 1065-1073 (1999).

105) L. Djogbénou, F. Chandre, A. Berthomieu, R. Dabiré, A. Koffi, H. Alout and M. Weill: PLoS One. 3, e2172 (2008).

106) L. Djogbénou, P. Labbé, F. Chandre, N. Pasteur and M. Weill: Malar. J. 8, 70 (2009).

108) D. H. Kwon, J. M. Clark and S. H. Lee: Insect Mol. Biol. 19, 195-204 (2010). 